\title{
Announcements
}

\section{World Arthritis Day 2017}

October 12, 2017 is World Arthritis Day (http://www. worldarthritisday.org). First observed in 1996, World Arthritis Day serves as a focus for organizations and individuals to work toward increasing awareness of arthritis and other rheumatic conditions worldwide. In the United States, 54 million adults (1) have some form of arthritis or other rheumatic condition. By 2040, the number of adults with arthritis is projected to increase $49 \%$ to 78.4 million, and the number of adults with arthritis-attributable activity limitation will increase $52 \%$, from 23 million to 34.6 million (2).

The theme of this year's World Arthritis Day is "Don't delay. Connect today." Early diagnosis and professionally guided management is important for maintaining a good quality of life, particularly for persons with inflammatory arthritis. There are four other things that persons with arthritis can do to help manage their arthritis: 1) learn arthritis management strategies, 2) be physically active, 3) maintain a healthy weight, and 4) protect their joints. Self-management education programs help persons with arthritis learn the strategies and gain the confidence to manage their condition, and improve pain control and function. Physical activity decreases pain, improves function, and delays disability; low impact, moderate intensity activities such as walking, cycling, water exercise, and fitness classes are safe and effective for persons with arthritis. Maintaining a healthy weight can limit disease progression and activity limitation, and avoiding joint injuries from sports or occupation can reduce the likelihood of developing osteoarthritis. Additional information on these interventions is available at https://www.cdc.gov/arthritis/interventions/index.htm.

\section{References}

1. Barbour KE, Helmick CG, Boring M, Brady TJ. Vital signs: prevalence of doctor-diagnosed arthritis and arthritis-attributable activity limitation-United States, 2013-2015. MMWR Morb Mortal Wkly Rep 2017;66:246-53. https://doi.org/10.15585/mmwr.mm6609e1

2. Hootman JM, Helmick CG, Barbour KE, Theis KA, Boring MA. Updated projected prevalence of self-reported doctor-diagnosed arthritis and arthritis-attributable activity limitation among US adults, 2015-2040. Arthritis Rheumatol 2016;68:1582-7. https://doi.org/10.1002/art.39692

\section{Global Handwashing Day - October 15, 2017}

October 15, 2017, marks the 10th annual Global Handwashing Day. This observance helps to increase awareness and understanding of handwashing with soap as an effective and affordable way to prevent disease around the world.

Handwashing with soap has an important role in child survival and health. Approximately 1.4 million children aged $<5$ years die each year from diarrheal diseases and pneumonia, the top two causes of death among young children globally (1). Handwashing with soap can reduce the incidence of diarrhea and respiratory infections among children in this age group by approximately $30 \%$ and $20 \%$, respectively $(2,3)$.

Although persons around the world clean their hands with water, few use soap to wash their hands, because soap and water might be less accessible in developing countries. Even when soap is available, it might be reserved primarily for laundry and bathing instead of for handwashing. Washing hands with soap removes germs more effectively than water alone (4), and can help in preventing diseases and saving lives. Additional information on Global Handwashing Day and handwashing in general is available from CDC at https://www.cdc.gov/ handwashing. Information on water-related hygiene is available at https://www.cdc.gov/healthywater/hygiene.

\section{References}

1. United Nations Children's Fund. One is too many: ending child deaths from pneumonia and diarrhoea. New York, NY: United Nations Children's Fund; 2016. https://data.unicef.org/wp-content/uploads/2016/11/ UNICEF-Pneumonia-Diarrhoea-report2016-web-version_final.pdf

2. Ejemot-Nwadiaro RI, Ehiri JE, Arikpo D, Meremikwu MM, Critchley JA. Hand washing promotion for preventing diarrhoea. Cochrane Database Syst Rev 2015;9:CD004265.

3. Aiello AE, Coulborn RM, Perez V, Larson EL. Effect of hand hygiene on infectious disease risk in the community setting: a meta-analysis. Am J Public Health 2008;98:1372-81. https://doi.org/10.2105/ AJPH.2007.124610

4. Burton M, Cobb E, Donachie P, Judah G, Curtis V, Schmidt WP. The effect of handwashing with water or soap on bacterial contamination of hands. Int J Environ Res Public Health 2011;8:97-104. https://doi. org/10.3390/ijerph8010097 
Announcement

\section{Community Preventive Services Task Force Finding for Year-Round Schooling to Increase Health Equity}

The Community Preventive Services Task Force (CPSTF) recently posted new information about its finding of insufficient evidence to determine the effectiveness of yearround schooling in improving academic achievement. The information for "Health Equity: Year-Round Schooling" is available at https://www.thecommunityguide.org/findings/ health-equity-year-round-schooling.

Established in 1996 by the U.S. Department of Health and Human Services, the CPSTF is an independent, nonfederal panel of public health and prevention experts whose members are appointed by the director of CDC. The CPSTF provides information for a wide range of persons who make decisions about programs, services, and other interventions to improve population health. Although CDC provides administrative, scientific, and technical support for the CPSTF, the recommendations developed are those of the task force and do not undergo review or approval by CDC.

\section{Erratum}

\section{Vol. 66, No. 35}

In the report "Update: Increase in Human Infections with Novel Asian Lineage Avian Influenza A(H7N9) Viruses During the Fifth Epidemic - China, October 1, 2016-August 7, 2017," on page 929, the last sentence of the first paragraph of the epidemiology section should have read "Among the 759 reported infections during the fifth epidemic, 14 clusters of two or three persons with Asian $\mathrm{H} 7 \mathrm{~N} 9$ virus infections were reported to WHO, compared with an average of $\mathbf{6 . 5}$ clusters in each of the previous epidemics (range $=4-11$ clusters)." 